\title{
The Excavation of an Early Bronze Age Burnt Mound at Arisaig, Lochaber, Highland
}

\author{
by Ian Suddaby* \\ with contributions by \\ Torben Ballin, Michael Cressey and Clare Ellis
}

Illustrations by Karen Clarke and Leeanne Whitelaw

*CFA Archaeology Ltd, Old Engine House, Eskmills Park, Musselburgh, East Lothian EH21 7PQ

Scottish Archaeological Internet Report 39, 2009 www.sair.org.uk 
Published by the Society of Antiquaries of Scotland, www.socantscot.org.uk with Historic Scotland, www.historic-scotland.gov.uk and the Council for British Archaeology, www.britarch.ac.uk

Editor Helen Bleck

Produced by Archétype Informatique, www.archetype-it.com

ISBN: 9780903903592

ISSN: $1773-3803$

Requests for permission to reproduce material from a $S A I R$ report should be sent to the Director of the Society of Antiquaries of Scotland, as well as to the author, illustrator, photographer or other copyright holder.

Copyright in any of the Scottish Archaeological Internet Reports series rests with the SAIR Consortium and the individual authors.

The maps are reproduced from Ordnance Survey material with the permission of Ordnance Survey on behalf of The Controller of Her Majesty's Stationery Office. (C) Crown copyright 2001. Any unauthorised reproduction infringes Crown copyright and may lead to prosecution or civil proceedings. Historic Scotland Licence No GD 03032G, 2002.

The consent does not extend to copying for general distribution, advertising or promotional purposes, the creation of new collective works or resale. 


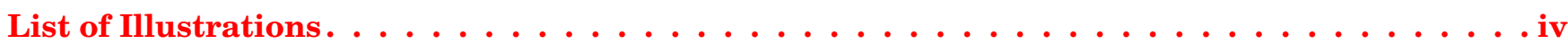

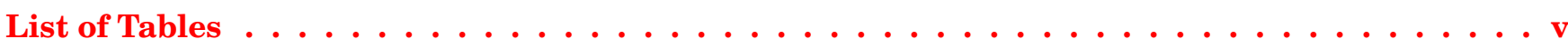

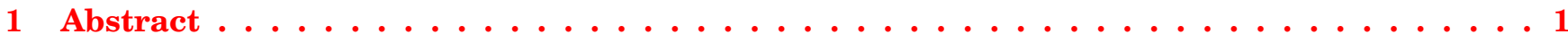

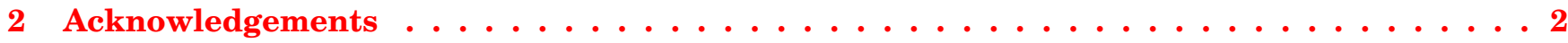

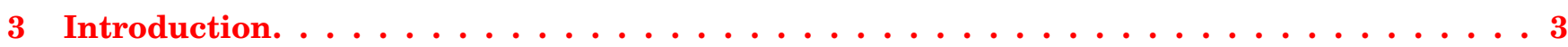

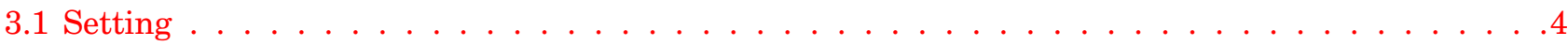

4 The Excavation . . . . . . . . . . . . . . . . . . . . . 6

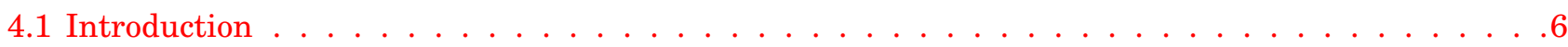

4.2 Phase 1 - Fluvial deposition of silts with evidence for vegetation. . . . . . . . . . . . . .6

4.3 Phase 2 - Deposition of burnt stone and charcoal into the palaeochannel . . . . . . . . . . . 6

4.4 Phase 3 - Fluvial deposition of silts with evidence for vegetation. . . . . . . . . . . . . . 6

4.5 Phase 4 - Deposition of spread of burnt stone and charcoal . . . . . . . . . . . . . . 6

4.6 Phase 5 - Fluvial erosion of burnt material, excavation of field drain and formation of field bank through site . . . . . . . . . . . . . . . . . . 10

5 The Finds and Environmental Evidence $\ldots \ldots \ldots \ldots \ldots \ldots \ldots$

5.1 The quartz assemblage, by Torben Bjarke Ballin. . . . . . . . . . . . . . . . . 11

5.2 Charcoal analyses, by Michael Cressey . . . . . . . . . . . . . . . . . . . . . 12

5.3 Soil micromorphology, by Clare Ellis . . . . . . . . . . . . . . . . . . . . . 13

5.4 Radiocarbon dates . . . . . . . . . . . . . . . . . . . . . . . . . . . . . . . . . . . . .

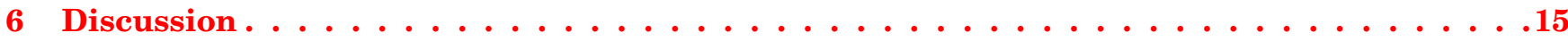

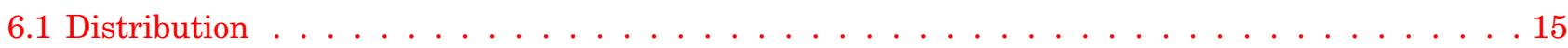

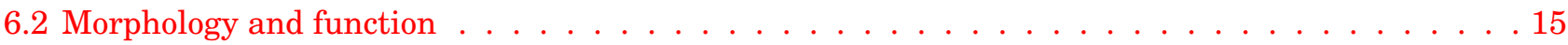

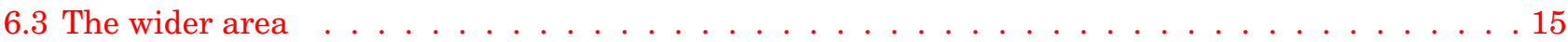

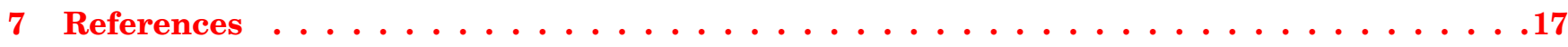




\section{LIST OF ILLUSTRATIONS}

Location map showing Arisaig and sites mentioned in the text . . . . . . . . . . . . . . . 3

The locality of the Arisaig site showing the stream and field bank . . . . . . . . . . . . . . .

Pre-excavation plan of the burnt mound showing section locations . . . . . . . . . . . . . .

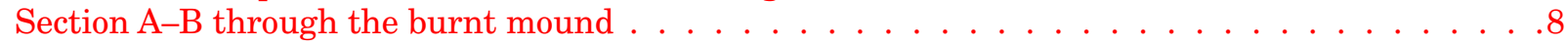

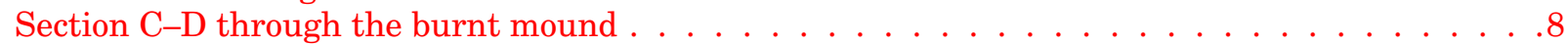

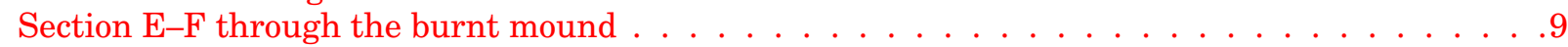

Section G-H through the burnt mound . . . . . . . . . . . . . . . . . . . . . 9

Section J-K through the field bank and underlying palaeochannels . . . . . . . . . . . . 10 


\section{LIST OF TABLES}

1

List of lithics . . . . . . . . . . . . . . . . . . . . . . . . . . . 11

2

Species represented by the charcoal $\ldots \ldots \ldots \ldots \ldots \ldots \ldots \ldots \ldots \ldots$

3

Radiocarbon dates from the Arisaig burnt mound . . . . . . . . . . . . . . . . . . . 14 



\section{ABSTRACT}

During the upgrading of the A830(T), the 'Road to the Isles', the remains of a disturbed burnt mound deposit were discovered and later excavated during September and October 2005 by CFA Archaeology Ltd. This is the first such feature to have been excavated in this part of the Highlands.

The burnt mound was discovered lying partly below a modern field bank on the edge of Arisaig during a trial trenching evaluation. Excavation demonstrated that the feature was formed in an active fluvial environment and that, despite the rural and boggy location, it had suffered considerable damage since its formation, caused by both the fluvial action of the adjacent stream and by a field drain. No evidence was found for either a hearth or a formal trough. The implication of a small assemblage of local quartz from within the burnt material is discussed. The charcoal assemblage is compared to spectra of pollen from contemporary deposits of peat in the area. Studies of the nature and origin of the burnt material via the results of soil magnetic susceptibility and thin-section analyses are presented. Six radiocarbon dates from three associated contexts span the period from 2550 to $1900 \mathrm{BC}$ and suggest the burnt mound accumulated during the Early Bronze Age. 


\section{ACKNOWLEDGEMENTS}

CFA Archaeology Ltd would like to thank Historic Scotland, and particularly Patrick Ashmore, for managing both the fieldwork and the post-excavation process, funding for which was provided by Transport Scotland on behalf of the Scottish Ministers. CFA also thank the specialist contributors. The excavation team comprised Alistair Curtis, Ian Hill, Leonard McKinney, Gemma Midlane, Paul Murtagh, Simon Olofsson and the author. Jimmy Smith of the Highland Council provided route maps, landowner information and advice throughout the project. The author would like to thank James Colston, manager of the Arisaig Estate on behalf of
Amphill Investments and the local residents who braved the mud in order to view the site. Steven Birch is thanked for allowing the use of unpublished radiocarbon dates from High Pasture Cave. The field drawings were prepared for publication by Karen Clarke and Leeanne Whitelaw. Drafts of the report were commented upon by Sue Anderson, Tim Neighbour and Rod McCullagh. The final form and opinions expressed in this report remain the responsibility of the author and CFA Archaeology Ltd.

The project was funded by Historic Scotland on behalf of Transport Scotland, an agency of the Scottish Government. 


\section{INTRODUCTION}

This report presents the results of the excavation of a burnt mound (NGR: NM 6667 8650) and associated palaeochannels undertaken by CFAArchaeology Ltd (CFA) between September and October 2005 prior to the upgrading of the A830 from Loch Nan Uamh to Arisaig. The excavations revealed two phases of burnt mound accumulation interspersed with three phases of erosion.

The burnt mound was discovered as a result of a programme of archaeological works along the route of the Loch Nan Uamh to Arisaig upgrade that included reconnaissance survey (Suddaby 2005 (a)),

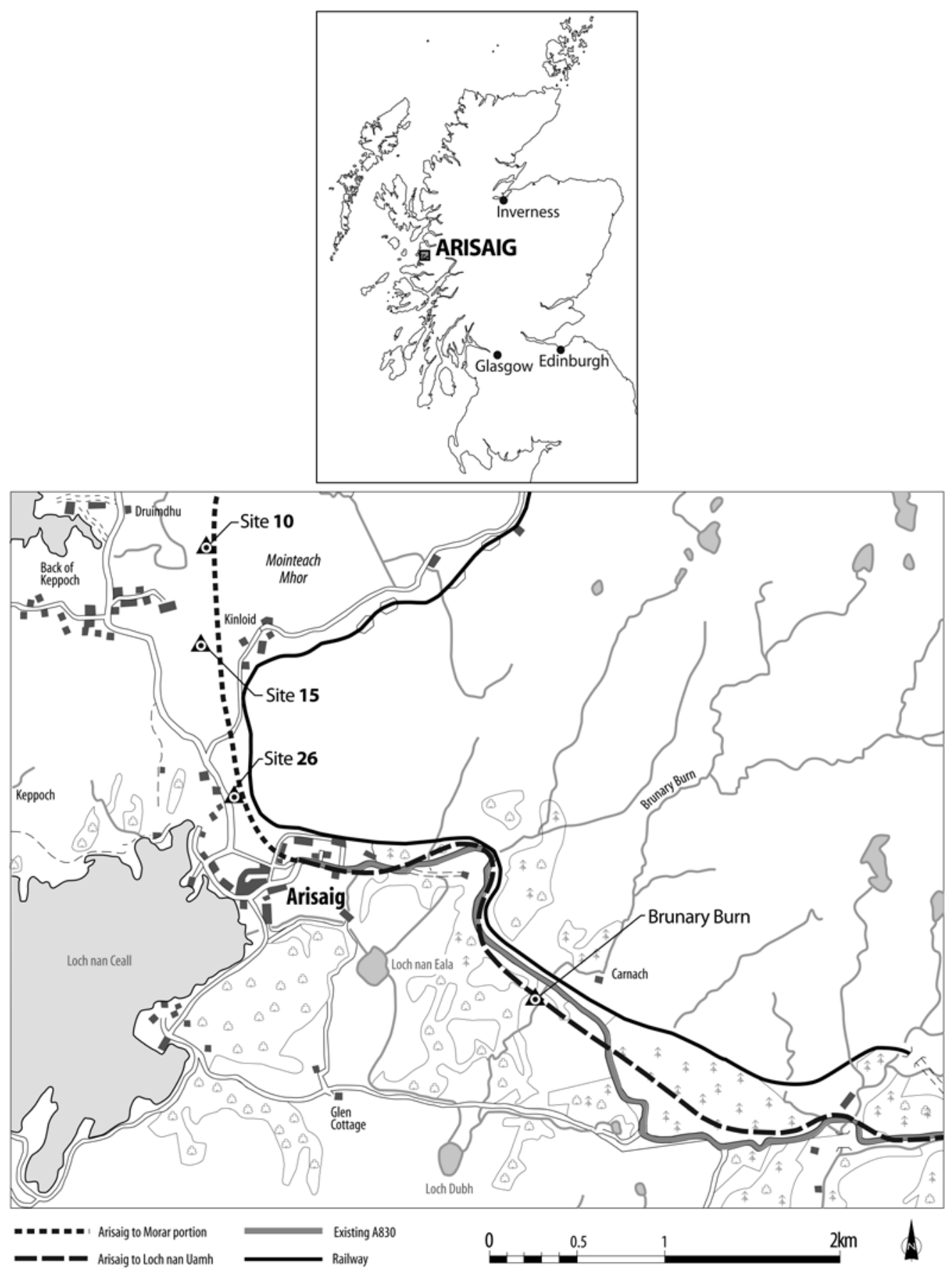

Illus 1 Location map showing Arisaig and sites mentioned in the text 
trial-trenching evaluation (Suddaby 2005 (b)) and excavation (Suddaby \& White 2006). Archaeological work during earlier phases of the overall upgrading of the A830 include that undertaken by Rees (1996) to the south, between Lochailort and Loch Nan Uamh and by Carter et al (2005) to the north, between Arisaig and Morar. The latter included the excavation of a cairn containing deposits dating to the Bronze Age (NM68NE 35), located 300m to the west of the burnt mound. Additional work on other sites around the Mointeach Mhor, further to the north, also revealed ephemeral Bronze Age activity. Two further cairns (NM68NE 6, 7) and a crannog (NM68NE 2) lie to the south. The location of these nearby sites and the burnt mound itself are shown on illus 1.

\subsection{Setting}

The burnt mound lies at $c 25 \mathrm{~m}$ OD, less than $1 \mathrm{~km}$ inland from the head of the sheltered Loch nan Ceall (illus 1) where the modern village of Arisaig is situated. To the east of the village, on generally south-facing gentle slopes, the improved grass fields extend westwards as far as a land boundary which is marked by a substantial grass-covered linear field-bank (illus 2). Immediately to the east, a small burn, which has been artificially channelled, drains the south slopes of Sgurr an t-Sasunnaidh. To the east of the burn is an area of semi-improved land which contains exposures of knobbly bedrock, large deciduous trees and localised areas of grass and bracken within which lazy-beds are present. To the north, beyond the existing A830, the ground rises steeply up to the railway and the unimproved hill land of Aird nam Fuaran beyond. To the south, the field-bank marking the improved land leads to Mains Farm and the canalised river draining Loch nan Eala.

Despite the straightening of the small burn, which passed within $2 \mathrm{~m}$ of the burnt mound (illus 2 ), the locality is poorly drained and boggy. The burn level rises appreciably when in spate and, prior to the formation of the field bank, must often have flooded the surrounding area. 


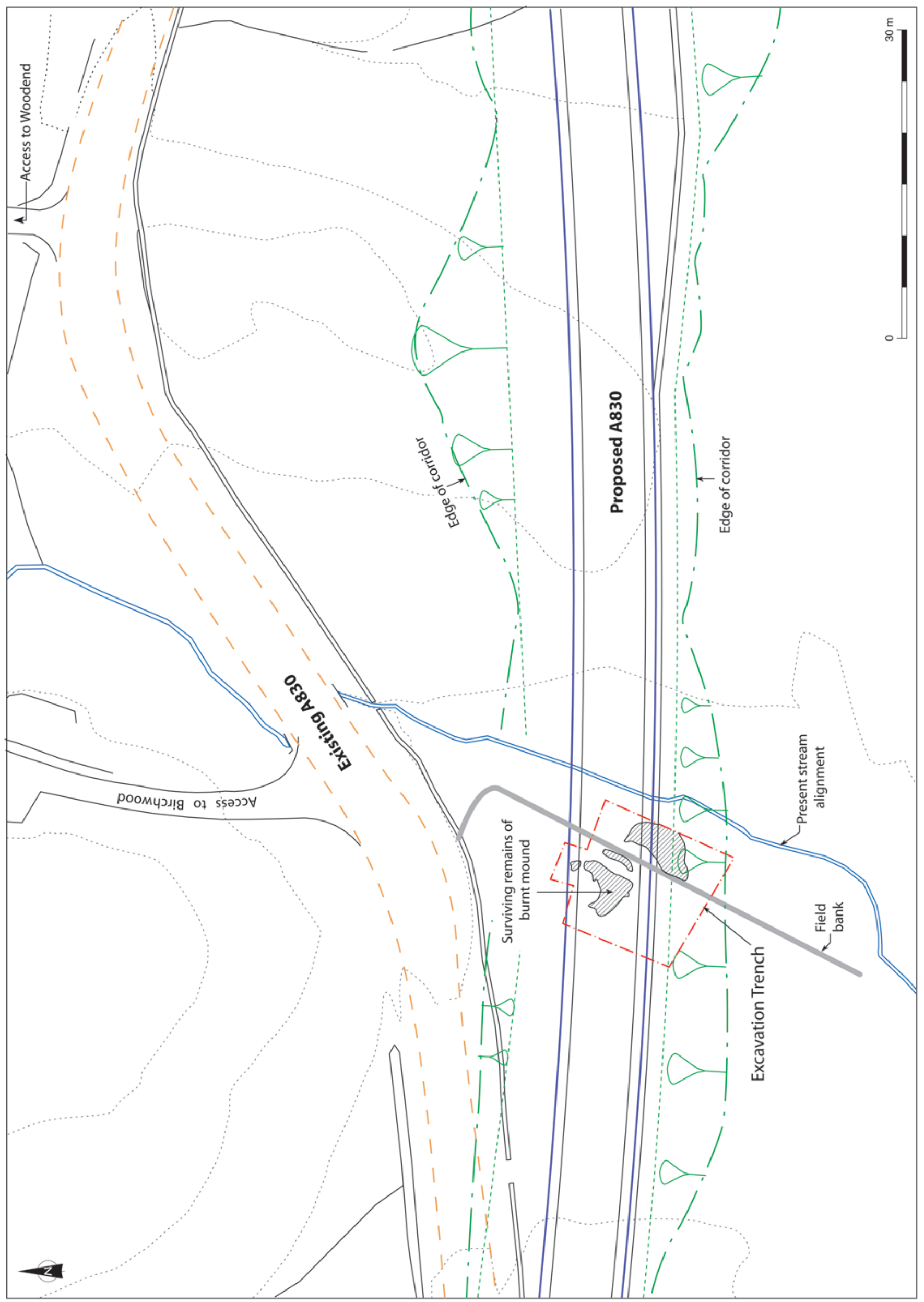

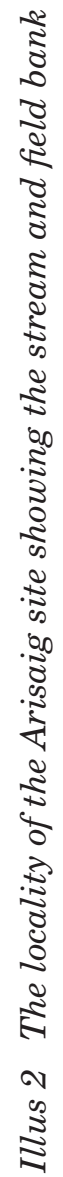




\section{THE EXCAVATION}

\subsection{Introduction}

A trench measuring $c 12 \mathrm{~m}$ by $13 \mathrm{~m}$ was excavated to encompass the entire extent of the burnt mound (illus 2). The size of the trench was defined by access constraints, the presence of large trees and the need to bund the topsoil within the road corridor. A combination of machine and hand excavation was used. All machine excavation was conducted using a tracked excavator with a flat-bladed bucket under constant archaeological supervision. The ground and the field bank were reinstated by machine on completion of the excavation. Illus 3 is a much-simplified plan of the excavation trench. For the sake of clarity many of the baulks are omitted, though they appear in the sections (illus 4-8).

Weather conditions during the excavation were challenging. Frequent rain made for muddy conditions and the need to transport spoil up from a low-lying trench entailed the use of wooden walking boards. Heavy overnight rain in mid September caused the burn to overflow and flood the site. The trench was pumped out and hosed down to remove accumulated silt without the need for re-cleaning, but further rain and constant water seepage from the adjacent burn dogged the excavation from then on.

The stones which made up the burnt mound formed a discrete area with clear margins, and although it had been disturbed over the years, the matrix in which the stones were laid contained substantial quantities of charcoal, suggesting that the bulk of the material from which the mound was composed had not moved significantly since its original deposition.

Five phases of deposition and human activity on the site were recognised and are described below.

\subsection{Phase 1 -Fluvial deposition of silts with evidence for vegetation}

Overlying a creamy-blue natural boulder clay (C050), a widespread deposit of fluvial fine sand and silt (C057, C060, C061, C073; illus 4) contained substantial and frequent degrading vertical roots and incorporated infrequent lumps of charred peat and lenses of organic silts. More localised deposits of peat (C065) were also noted. Overlying these deposits, at two stratigraphically unconnected locations on either side of the field drain (C036), were deposits of anthropogenic origin.

\subsection{Phase 2-Deposition of burnt stone and charcoal into the palaeochannel}

In Phase 2 (illus 3-5, Sections A-B, C-D), a layer of burnt stones and charcoal (C040), 0.2m deep at most was dumped on the Phase 1 fluvial sand and silt. The location may have been accompanied by a marker post, represented by a square-section stakehole (C044), $0.15 \mathrm{~m}$ deep and $0.08 \mathrm{~m}$ wide. In profile the base of C040 is slightly concave and it appears that it was dumped into a natural gully. Deposit C040 was distinguished from others of similar material by being composed of stones that were not reddened by oxidisation in heat or by subsequent exposure to air. Samples of hazel charcoal in $\mathrm{C} 040$ were dated to 2460-2030 cal BC (GU-14990-1, table 3).

To the north (illus 3, 6, Sections E-F, G-H), what may be the terminal of a peat-filled palaeochannel (C049, C095) had apparently been modified by limited shaping of the edges and was further defined by the adding of a number of large stones (C070, C102). After abandonment, this feature became filled with a mixed deposit comprising reworked peat, degrading heat-affected stone and charcoal (C012, C069, C100, C103-4).

\subsection{Phase 3-Fluvial deposition of silts with evidence for vegetation}

Overlying C040 were further laminated silt and sand deposits (C039/C048, Phase 3) with a depth of $0.3 \mathrm{~m}$, representing a second period of fluvial deposition. Charcoal from within it was dated to between 2550 and 2040 cal BC (GU-14988-9, table $3)$. The overlying silt (C047) was a brighter yellow than $\mathrm{C} 039 / \mathrm{C} 048$ but a suggestion that it was heat affected is not supported by soil tests. Deposit C047 appeared to have been laid onto a truncated surface as the laminations within C039 were inclined at $c$ $30^{\circ}$. It is therefore different in origin and a manifestation of changing, but ongoing, activity in the area.

Overlying the palaeochannel terminal, a thick layer of creamy-yellow fine sand and silt (C019/C035/ C091) was again stratigraphically unconnected to those to the south but may equate to C039/C048.

\subsection{Phase 4-Deposition of spread of burnt stone and charcoal}

The Phase 3 deposits of water-lain fine sand and silt were overlain by the burnt mound itself (C003, C007, C011, C021, C025, C055). Now measuring $c$ 


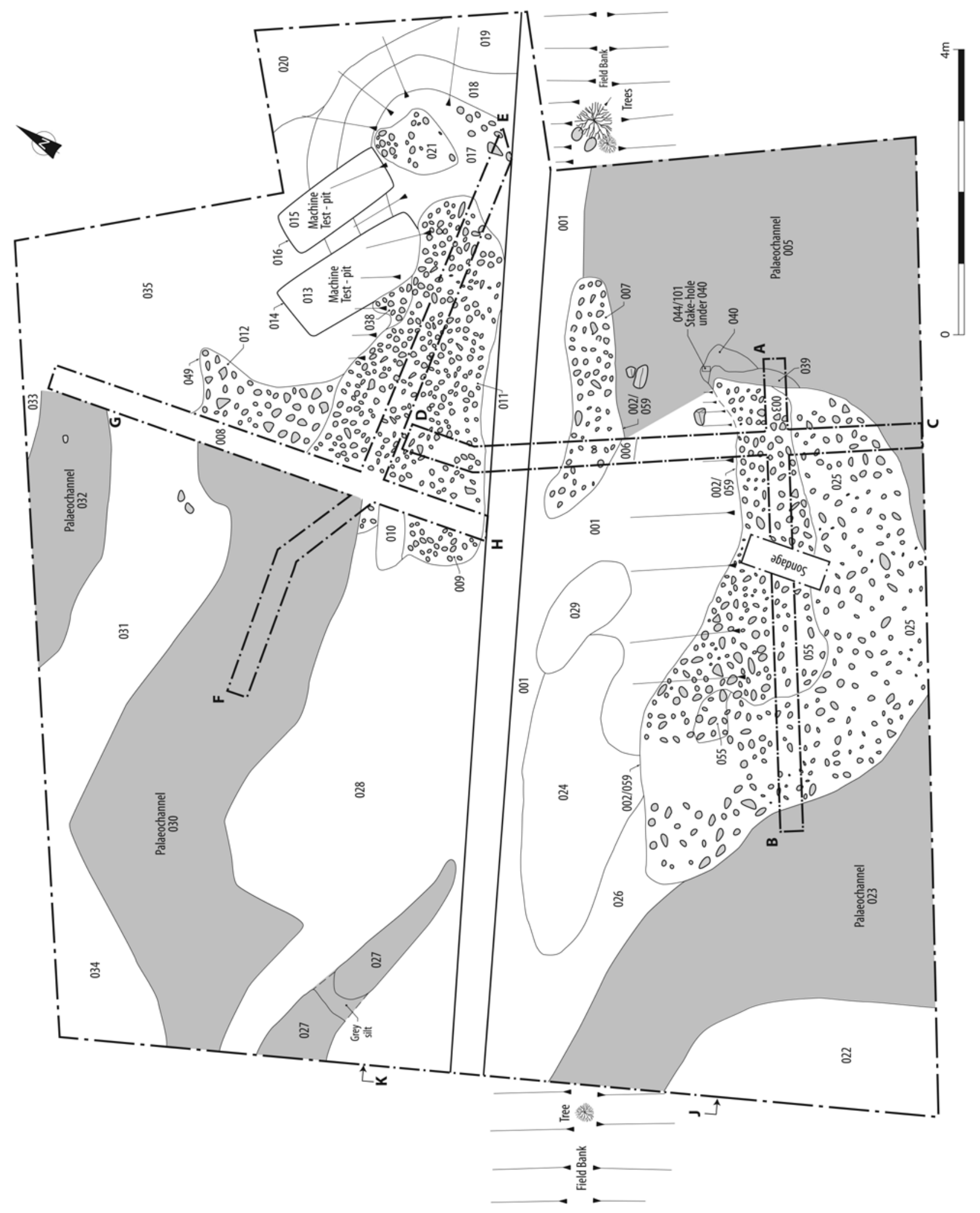

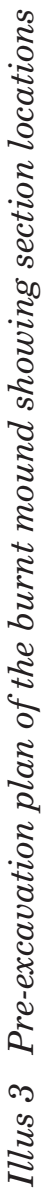




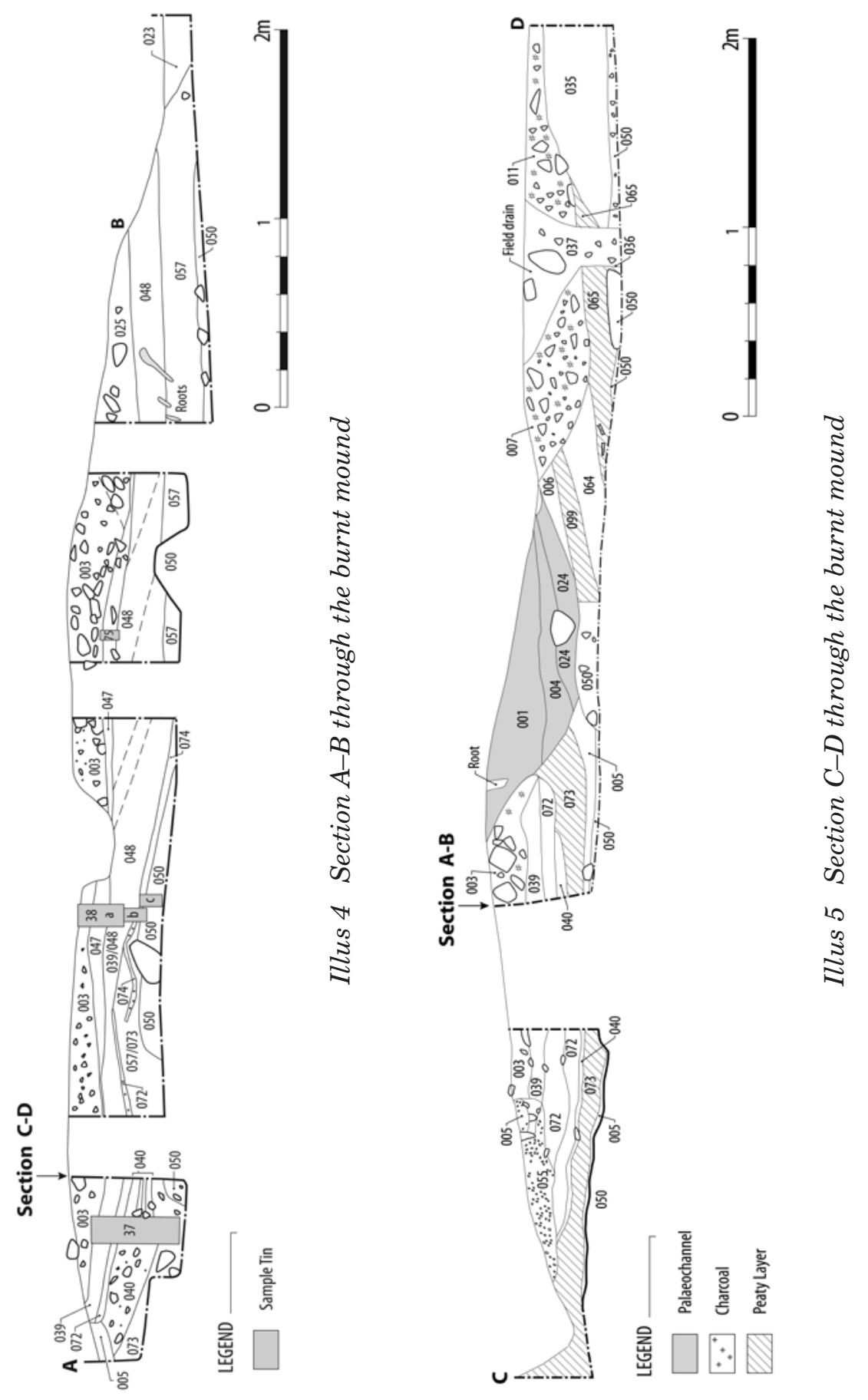




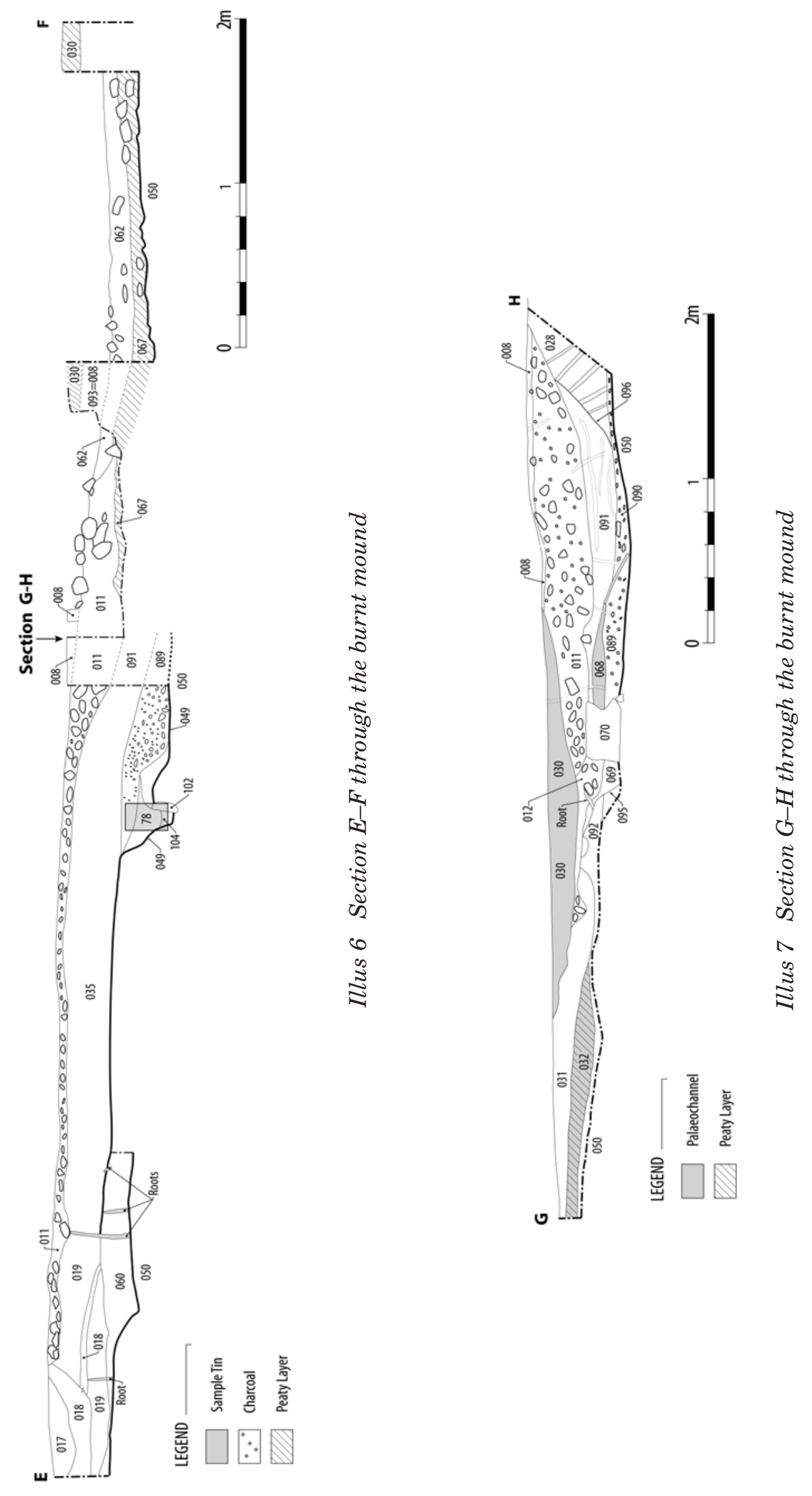




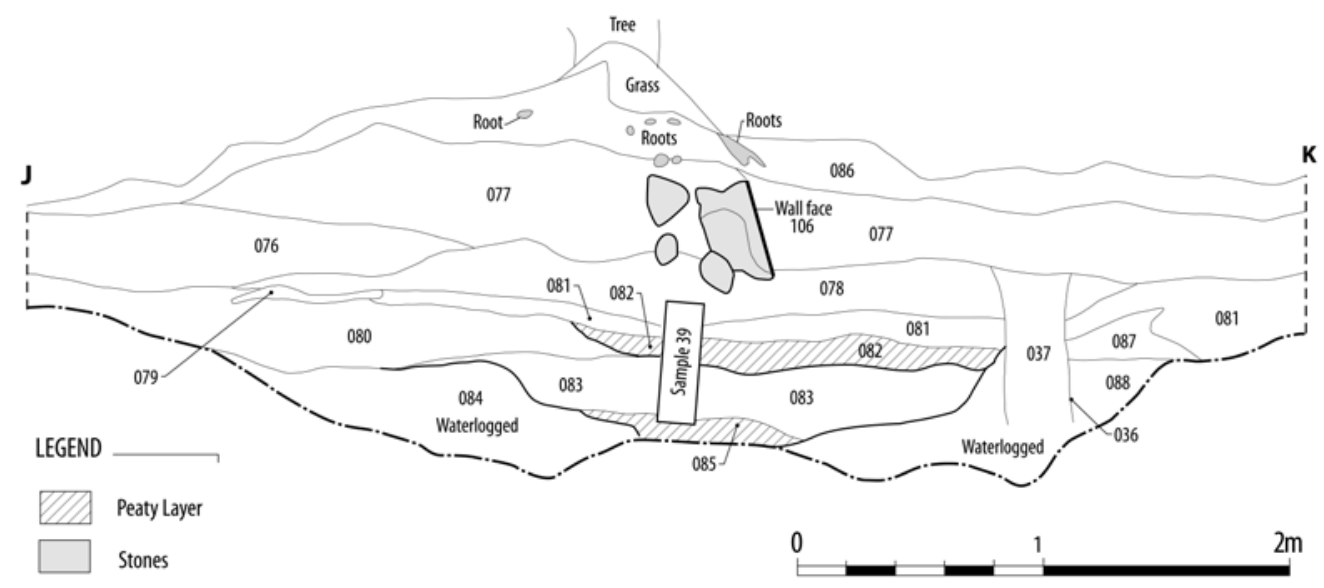

Illus 8 Section J-K through the field bank and underlying palaeochannels

$11 \mathrm{~m}$ by $7 \mathrm{~m}$, this spread had been divided into three discrete deposits, none of which was over $0.35 \mathrm{~m}$ deep and much of which was reduced to $0.1 \mathrm{~m}$ or less. The deepest part was C007, where section C-D (illus 5) shows that it, and the southern part of C011, filled what may be a palaeochannel with a concave section, as was the case with C040. Elsewhere, deposition appeared to have been onto the surfaces of sandbanks. Charcoal in C003 was dated (GU14992-3, table 3) to between 2210 and 1900 cal BC. Whereas C011 and C007 were homogeneous in nature, the main (C003), most elevated spread of burnt material in the south of the site contained two areas of brighter-red stones (C025, C055), caused by oxidation in a relatively dry location. This area was overlain by numerous roots running under the burn from the mature alder trees to the south and the matrix around the stones had been disturbed, probably by root action; indeed vertical roots were mistaken for wooden stakes during the evaluation. Post-depositional compaction was evidenced by stones being pressed into the underlying deposits (eg C017, C047).

\subsection{Phase 5 - Fluvial erosion of burnt material, excavation of field drain and formation of field bank through site}

The Phase 4 burnt mound had been affected by more recent fluvial erosion and human activity. This led to it being cut into three discrete deposits (C003/C025/C055, C007 and C011/C021). To the north-west (illus $3,6,7$ ) of $\mathrm{C} 011 / \mathrm{C} 021$, eroded deposits were preserved in a shallow palaeochannel.
There, overlying the natural subsoil (C050) in the base of the palaeochannel was a thin deposit of peat (C067), which was overlain by $\mathrm{C} 011$ which contained frequent reddened stones. Deposit C011 was overlain by $\mathrm{C} 062$, which was charcoal-rich, with few incorporated stones, and would appear to have been eroded from the main area of burnt material. Finally, C062 was overlain by a mixed deposit of peat and charcoal flecks (C008) with more sterile peat (C030) filling a second palaeochannel (illus 7), overlying the first.

Further palaeochannels (C005, C023) cut the burnt mound to the east and west of the main deposit. The bases of both were filled with a mixture of small cobbles, finer material and degrading wood. That to the east (C005) was not fully revealed in the excavation trench but was at least $3 \mathrm{~m}$ in width and was responsible for vertically truncating the edges of C003, C039, C040 (Section A-B, illus 3-4), exposing this sequence of deposits. The palaeochannel to the west (C023) was filled with similar material, with both being similar to that filling the existing canalised burn. All contrast with those in the palaeochannels (eg C030) to the north which may have been formed by different streams originating as runoff from the fields to the north (illus 2).

In the east-facing trench section, (Section J-K, illus 8), two palaeochannels were present. The earlier example was predominantly filled with peat (C085) under sand, small gravel and burnt stones (C083) and appears to be a continuation of $\mathrm{C} 023$. The latter contained a brown humified peat (C082), with charcoal flecked silts (C078, C081) above. These deposits were overlain by the field bank (C075) with its stone face (C106). 


\section{THE FINDS AND ENVIRONMENTAL EVIDENCE}

Finds from the excavation were sparse. A single quartz flake was found in the Phase 2 burnt deposit C040. Several additional lithic artefacts were recovered from the bulk samples after flotation. The assemblage was completed by a whiteware rimsherd, dating to the 19th century, recovered from the bank material (C075) behind (C106).

\subsection{The quartz assemblage, by Torben Bjarke Ballin}

Twelve quartz artefacts were recovered from the site (table 1). A full catalogue of the artefacts is included in the site archive.

\subsubsection{Raw material: types, condition and sources}

A single form of quartz was encountered at the site: ordinary white milky quartz. All twelve pieces had been exposed to fire, resulting in varying degrees of 'granulation' (Ballin forthcoming (a)). Limited exposure had caused some pieces to appear lightly saccharoidal, whereas more extensively exposed pieces are heavily crazed and in an advanced state of disintegration. Several pieces are discoloured brown, but it is not possible in most cases to say whether this is an effect of heating, or whether it is due to iron pan formation (two are definitely affected by iron pan). Most pieces are covered by a dusting of charcoal particles.

All the quartz artefacts are tertiary, or inner, pieces with no trace of cortication. This makes it impossible to determine whether the quartz was procured from pebble or vein sources (the combined use of pebble and vein quartz is suggested by Lacaille in his paper on the nearby site of Rudha'n Achaidh Mhoir (Lacaille 1951). Analysis of quartz assemblages on the Western Isles (Ballin forthcoming (a)) suggests that quartz was usually not traded, but procured locally.

Table 1 List of lithics

\begin{tabular}{lc}
\hline Platform flakes & 1 \\
Bipolar flakes & 2 \\
Indeterminate flakes and flake fragments & 2 \\
Indeterminate pieces (incl. chunks) & 7 \\
Total & 12 \\
\hline
\end{tabular}

\subsubsection{Typological and technological assemblage composition}

Only debitage was recovered from the burnt mound, cores and tools were absent. Five pieces are flakes or flake fragments and seven pieces are indeterminate (table 1). One piece from $\mathrm{C} 040$ is a hard-hammer flake, with two pieces from $\mathrm{C} 011$ being bipolar flakes. Two specimens from C003 and C011 are indeterminate flake fragments.

The technological attributes of the flakes indicate that two different approaches were followed. The hard hammer flake from C040 shows that, in this case, the platform-edge of a core was carefully trimmed before the flake was detached from its parent core. Remains of an older, trimmed and abraded platform-edge indicate that this core may have been a roughly cubic piece with at least two platforms, that is, either a core with two platforms at an angle or an irregular (multi-directional) core. The bipolar flakes were detached from their parent cores by the application of the so-called hammerand-anvil technique.

Platform and bipolar techniques were frequently combined within one operational schema (ibid), with larger nodules being shaped into single-platform cores. When a single-platform core had been reduced somewhat, production flaws occasionally made it necessary to re-define the core by making a new platform-edge along an appropriate edge, and in most circumstances the core became a core with two platforms at an angle and, later, an irregular core with three or more platforms. Finally, when the core had become too small to allow further reduction in platform technique, the exhausted core was reduced in bipolar, or hammer-and-anvil, technique, before it was abandoned.

The indeterminate pieces may be results of quartz cores breaking up along inherent planes of weakness, rather than flaking in a conchoidal manner, or they may be the remains of more regular quartz artefacts which shattered as a result of the exposure to fire.

\subsubsection{Stratigraphy and dating}

Nine of the twelve recovered quartz artefacts were found in the Phases 2 and 4 burnt material. This indicates that in all probability the assemblage was deposited by the people who formed the burnt mound.

Unfortunately, the attributes of the quartz debitage do not allow precise dating of the pieces. Quartz hard-hammer and bipolar flakes were produced throughout Scottish prehistory, but the use of 
Table 2 Species represented by the charcoal

\begin{tabular}{llcc}
\hline Species & Common name & No. of identifications & Weight (g) \\
\hline Corylus avellana & Hazel & 269 & 53.96 \\
Betula sp. & Birch & 64 & 10.35 \\
Quercus sp. & Oak & 10 & 1.20 \\
Alnus glutinosa & Alder & 4 & 0.50 \\
Salix sp. & Willow & 4 & 1.90 \\
Pinus sylvestris & Pine & 1 & 0.10 \\
Total & & 352 & 68.01 \\
\hline
\end{tabular}

abrasion (even in the absence of deliberate platform faceting) is consistent with a Late Neolithic date (see for example the attribute analysis of selected blank assemblages from Stoneyhill in Aberdeenshire; Ballin forthcoming (b)). However, some Middle Bronze Age quartz assemblages from Shetland had been surprisingly carefully prepared (cf the assemblage from Bayanne on Yell and the material from the Cruester Burnt Mound on Bressay; Ballin forthcoming (c); forthcoming (d)). Indirectly, the Arisaig pieces are dated by their incorporation into the fill of the burnt mound.

\subsection{Charcoal analyses, by Michael Cressey}

\subsubsection{Introduction}

Analysis of the charcoal from the burnt mound provides a useful index of the types of wood exploited for fuel and an indication of the composition of the local woodland. It is also a prerequisite of radiocarbon dating sample selection.

\subsubsection{Methodology}

A system of flotation and wet sieving was used to separate the archaeological material from soil samples. Initially the floating debris was collected in a $300 \mu \mathrm{m}$ sieve and, once dry, scanned using a low-powered binocular microscope (magnification $\times 10-\times 200)$ to identify the archaeological material. Selected charcoal samples were also retrieved from soil samples contained in Kubiena tins. Material remaining in the flotation tank was wet sieved through a $1 \mathrm{~mm}$ mesh and air-dried before being sorted to identify any remaining significant material.

Charcoal identifications were made using a binocular microscope (magnification $\times 10-\times 200$ ) to view transverse cross-sections of charcoal pieces between $2 \mathrm{~mm}$ and $4 \mathrm{~mm}$ in size. Anatomical keys listed in Schweingruber (1992) and in-house reference charcoal samples were used to aid identification. Charcoal identifications ceased when 25 individual samples of a given species were reached.

\subsubsection{Results}

Three hundred and fifty-six individual charcoal samples derived from twelve contexts have been examined. Both vitrified and partially fired charcoal were present and a proportion were below the size suitable for identification.

\subsubsection{Interpretation}

Six species of wood have been used for fuel within the charcoal assemblage from the burnt mound. The order of abundance is shown in table 2. In general terms the charcoal was amorphous, having no regular cylindrical shape, typical of branchwood. Taphonomic processes, namely compression under mineral-rich layers and a fluctuating water table, will have caused saturation. Together, these will have had an effect on the preservation of the assemblage.

The variability of charcoal between the contexts is also noticeable, with only four samples producing over 25 counts of charcoal; these comprised contexts C011, C040, C062 and C100.

\subsubsection{Species composition of the fuel}

Hazel is the most common wood exploited and would have been common within the local wildwood close to the site. Birch and oak are likely to have been as common as hazel, but both are under-represented within this assemblage. Alder and willow are present but very low in frequency. Both species are suited to saturated or seasonally flooded land, and land beside streams. Pine is represented by a single fragment.

Based on the above evidence, the local woodland close to the burnt mound would have included stands of hazel, possibly as an under-storey shrub below oak. Birch would have been established in more open areas, along with pine; both are highly tolerant of the base poor soils within the study area. Based on a large number of charcoal studies from Scottish contexts, pine appears to be under-represented, and this may be due to its high resin content and its ability to burn hotly and rapidly (Taylor 1981). 


\subsubsection{Discussion}

The vitrified fragments that were identified by the glass-like alteration to the vascular cell structure of the wood strongly suggest that temperatures were sufficiently high to have reached the state where the charcoal was extremely altered. Ignition above $500^{\circ} \mathrm{C}$ occurs during the stage of pyrolysis when the right conditions allow the wood to glow and turn into ash if enough oxygen is available (Beall 1972). Where reducing conditions have been reached (ie where little oxygen is present), the conversion of wood to charcoal will be more prevalent. The charcoal is likely to represent only a fraction of that used during the lifetime of the burnt mound. Charcoal vitrification is likely to occur when such fragments have been re-heated either through deliberate or accidental burning. Such differences as may arise in burning conditions (temperature, intensity of fire, length of exposure, heating environment) and wood properties (size, moisture content, taxa, anatomical structure) have a direct effect on taxonomic representation within a wood charcoal assemblage. Small-sized woods such as shrubs, which may also be used as kindling, are more likely to be consumed entirely in lower temperatures, whereas pieces of wood lying at the centre of the fire heat faster and thus can burn completely (Smart \& Hoffman 1988). On the other hand, charcoal that is buried in the ash at the bottom of the hearth has a greater chance of preservation, due to lack of oxygen (ibid).

Based on vegetation reconstruction at Carnach Bog, approximately $1.5 \mathrm{~km}$ to the south-east of Arisaig (Cressey \& Verrill 2006), the first indication of human activity occurs in the Middle to Late Bronze Age, with elevated grass pollen levels and an overall decline in arboreal pollen. Hazel pollen was found to have responded to an increase in open spaces. Domestic exploitation of the local woodland would certainly have had a local impact during the lifetime of the burnt mound, and hazel appears to have been locally abundant.

\subsection{Soil micromorphology, by Clare Ellis}

\subsubsection{Introduction}

Six Kubiena tin samples were analysed from deposits associated with the burnt mound, with the aim of elucidating the contemporary depositional environment. The summary results are given below. Full descriptions appear in the archive report.

\subsubsection{Descriptions}

Samples 37A to E covered the lower portion of the profile of the possible burnt mound, with Sample $38 \mathrm{~A}$ covering the upper portion. The positions of the samples are shown on illus 4 .

The Phases 1 and 3 sandy peat and laminated silts and sands (C039, C057/C073) were generally well compacted with complex to massive microstructures, whereas the Phases 2 and 4 burnt material (C040, C003) exhibited open, granular soil microstructures. The former was dominated by decomposed organic matter, while the latter was generally masked by phosphate and/or goethite. Comminuted, evenly dispersed charcoal occurred throughout and was dominant in Phases 2 and 4. Although the profile had been affected by post-depositional root penetration, disturbance by soil biota was minimal. Iron deposits (goethite) dominated the uppermost layers (C047, C003).

\subsubsection{Conclusions}

- Phase 1 deposits accumulated within relatively slow-moving water.

- Phase 2 deposit C040 was dumped in its present location.

- Phase 3 deposits accumulated under fluvial conditions with occasional deposits and lenses of ash attesting to continued, nearby human activity. The final Phase 3 deposit was largely derived from ash but was reworked and deposited in a fluvial environment.

- Phase 4 deposits were dumped in their present location.

\subsection{Radiocarbon dates}

Six samples were sent for AMS dating at the Scottish Universities Environmental Research Centre (SUERC). All derived from charcoal recovered from column samples collected during the excavation. These were kept in a temperature-controlled environment during storage.

Four dates from two contexts $(\mathrm{C} 003, \mathrm{C} 040)$ relate to Site Phases 2 and 4. The remaining two dates (C039) relate to charcoal inclusions within Phase 3 deposits. The results are shown in table 3 . The dates indicate that the burnt material at Arisaig was deposited in the second half of the third millennium cal BC.

All six dates were determined from constituent parts of redeposited contexts. None date the deposition of the charcoal in the location from where it was recovered. The date derived from oak is the oldest of the determinations. The remaining dates were derived from hazel, which may have been coppiced and hence younger at the time of burning than the oak. The dates are closely grouped and there is no evidence for either a significant gap between the combustion of the wood and the deposition of the charcoal in the burnt mound, or of post-depositional processes affecting the integrity of the layers.

The sequence of dates shows that deposits C040 and C039 are very similar in age. The overlying context $\mathrm{C} 003$ provides the most recent of the paired dates. 
Table 3 Radiocarbon dates from the Arisaig burnt mound

\begin{tabular}{|c|c|c|c|c|c|}
\hline $\begin{array}{l}\text { Context } \\
\text { (Sample) }\end{array}$ & Lab Code & RC Date & Material & Delta 13 C & $\begin{array}{l}\text { Calibrated Date } \\
\text { BC }\end{array}$ \\
\hline C039 (1) & $\begin{array}{l}\text { SUERC-13244 } \\
\text { (GU-14988) }\end{array}$ & $3785 \pm 35$ & Hazel & $-27.1 \%$ & $\begin{array}{l}2290-2140(1 \sigma) \\
2340-2040(2 \sigma)\end{array}$ \\
\hline C039 (2) & $\begin{array}{l}\text { SUERC-13245 } \\
\text { (GU-14989) }\end{array}$ & $3920 \pm 35$ & Oak & $-25.5 \%$ & $\begin{array}{l}2480-2340(1 \sigma) \\
2550-2290(2 \sigma)\end{array}$ \\
\hline C040 (3) & $\begin{array}{l}\text { SUERC-13246 } \\
(\text { GU-14990) }\end{array}$ & $3745 \pm 35$ & Hazel & $-26.1 \%$ & $\begin{array}{l}2210-2050(1 \sigma) \\
2280-2030(2 \sigma)\end{array}$ \\
\hline $\mathrm{C} 040$ (4) & $\begin{array}{l}\text { SUERC-13247 } \\
\text { (GU-14991) }\end{array}$ & $3805 \pm 40$ & Hazel & $-26.4 \%$ & $\begin{array}{l}2300-2140(1 \sigma) \\
2460-2130(2 \sigma)\end{array}$ \\
\hline C003 (5) & $\begin{array}{l}\text { SUERC-13251 } \\
\text { (GU-14992) }\end{array}$ & $3635 \pm 35$ & Hazel & $-27.3 \%$ & $\begin{array}{l}2120-1940(1 \sigma) \\
2140-1900(2 \sigma)\end{array}$ \\
\hline C003 (6) & $\begin{array}{l}\text { SUERC-13252 } \\
\text { (GU-14993) }\end{array}$ & $3710 \pm 35$ & Hazel & $-27.7 \%$ & $\begin{array}{l}2190-2030(1 \sigma) \\
2210-1970(2 \sigma)\end{array}$ \\
\hline
\end{tabular}

The dates from Arisaig fall in the earlier end of the date-range for burnt mound sites in Scotland (Barber 1990, table 4). They are most similar to those from Machrie Moor on Arran (Barber \& Lehane 1990) and Borichill Mor on Islay (RussellWhite \& Barber 1990). 


\section{DISCUSSION}

\subsection{Distribution}

The burnt mound at Arisaig is the first to be recorded in Lochaber and is therefore an important contribution to our understanding of the distribution of these features.

Hedges $(1975,61)$ summarised the recorded distribution of burnt mounds within the British Isles as the extreme north (Shetland, Orkney and Caithness) and a large part of the west (Ireland, Wales, Isle of Man, south-west Scotland, Staffordshire, Warwickshire and the New Forest). More recent work has extended this distribution to the Moray Firth (Cressey \& Strachan 2003), Cumbria (Nixon 1990; Neighbour \& Johnson 2005; Heawood \& Huckerby 2002) and the Western Isles (Armit \& Braby 2002; Birch et al forthcoming). The nearest recorded burnt mound is at High Pasture Cave, near Torrin on the Isle of Skye (ibid).

Although the Arisaig burnt mound is remote from other similar sites, recent excavation and field survey have served to fill in some of the gaps in the burnt mound distribution map in the Highlands (Cressey \& Strachan 2003, fig. 7). As well as large clusters in the north and east of the region, this shows small groups and isolated finds dotted along the bays and inlets of the west coast. How much this is a function of the location of commercial developments, and therefore rescue archaeology, is a matter for conjecture, but none of the three recently added burnt mound sites on the west coast, Arisaig, Ceann nan Clachan on North Uist (Armit \& Braby 2002) and High Pasture Cave (Birch et al forthcoming), were initially visible in plan. All may therefore have escaped detection without an additional force at work, be that coastal erosion, research excavation, commercial development or infrastructure improvements.

\subsection{Morphology and function}

The results of the excavation concord with many of the widely accepted traits of burnt mounds. At Arisaig, missing features include the lack of a hearth and a formal trough. Both may well be a consequence of more recent fluvial activity and human land use patterns, or the location of these features beyond the limits of the excavation, rather than a deviation from the expected character.

In terms of the morphology of the varied sites containing similar burnt material, few exhibit the classic crescent (fulachta fiadh) appearance of Barber's Class 1 (Barber 1990), most of which are dated to the Bronze Age. Often, as at Arisaig, they have been reduced to an amorphous spread by ploughing, landscaping or erosion and may indeed survive only in underlying negative features and spreads (eg Neighbour \& Johnson 2005), without overlying similar deposits and with consequent visibility problems. Whilst the volumes of burnt material being produced at many sites would have prohibited their disposal below ground, it is clear that this material was also deposited in smaller quantities both within and outside settlements.

Two phases of burnt stone deposition are present at Arisaig, both pre-dated and post-dated by fluvial erosion and deposition. The earlier fluvial episode is represented by the modification of a palaeochannel terminal (C049), which may equate to the dumping of deposit C040 by stake-hole C044, although there is no direct stratigraphic link. The second phase post-dates the first by an unknown but short period of time during which the local morphology of the area may have changed significantly, with channels infilling and the deposition of silt and sand. There then followed a period when more extensive volumes of burnt stones were dumped.

Thin-sectioning of the deposits below each deposit of burnt stone has allowed further insight into the processes at work. It is suggested that differences in microstructure reflect the redeposition of the material after burning. The stones were therefore not heated on the sandbank and the location of the hearth may have been at some distance from the dumping site - as with all burnt mounds, there is no expectation of in situ burning.

Burnt mounds have been variously claimed to be cooking places (O'Kelly 1954), saunas (Barfield \& Hodder 1987) and, most recently, breweries (Peterkin 2007). This uncertainty stems from the unrewarding nature of burnt mounds in terms of artefacts and as a contribution to our understanding of past processes, facts well highlighted by Russell-White $(1990,59)$ and Barber. Arisaig is exemplary in this regard. The lithics may be a slight oddity amongst Early Bronze Age burnt mounds, but otherwise the site was sterile and the deposits gave no indication of their original function. Vitrifaction in some of the charcoal suggests a high temperature, but both the process and intention are unclear.

\subsection{The wider area}

In terms of comparisons with palaeoenvironmental data from the surrounding area, two studies are of relevance. These derive from Mointeach Mhor to the north (Carter et al 2005) and from Carnach to the south-east (Cressey \& Verrill 2006). Both suggest 
that human influence on the landscape prior to the Bronze Age was minimal.

At Carnach Bog, $1.5 \mathrm{~km}$ to the south-east, the Early Bronze Age levels suggest sporadic occurrences of disturbed ground. Pastoral indicator species were intermittently recorded and micro-charcoal was negligible. These indicator species expand in the Middle Bronze Age and arboreal pollen declines. There is evidence of hazel expanding into these open spaces.

Three and a half kilometres to the north of Arisaig on Mointeach Mhor, a similar peat core suggests limited woodland usage from the Late Neolithic (3200 BC), when a decline in tree pollen is matched by a rise in micro-charcoal. Taxa associated with disturbed ground increase from 1500 BC.
Mointeach Mhor and Carnach are in less favourable locations than the Arisaig burnt mound. Both are more boggy, Carnach is further from the sea, and Mointeach Mhor is more exposed. Assuming local pollen is dominant in the profiles from these locations, it is likely that they fail to reflect the true extent of settlement in the area, which, if concentrated around Arisaig, perhaps made only marginal impacts in the hinterland. Archaeological evidence for the Arisaig area in the Early Bronze Age is restricted to cairns, artefact scatters and cists. The burnt mound at Arisaig is an important addition to these remains, and to our knowledge of Early Bronze Age habitation along the west coast. 


\section{$7 \quad$ REFERENCES}

Armit, I \& Braby, A 2002 'Excavation of a burnt mound and associated structures at Ceann nan Clachan, North Uist', Proc Soc Antiq Scot, 132 (2002), 229-58.

Ballin, T B forthcoming (a) Quartz Technology in Scottish Prehistory. SAIR, Edinburgh (http:// www.sair.org.uk).

Ballin, T B forthcoming (b) 'The lithic assemblage', in I Suddaby 'Stoneyhill Landfill Site, near Peterhead, Aberdeenshire', Proc Soc Antiq Scot.

Ballin, T B forthcoming (c) 'The quartz assemblage' in $\mathrm{H}$ Moore \& G Wilson The Bayanne Project, Shetland. Shetland Amenity Trust Monograph, Lerwick

Ballin, T B forthcoming (d) 'The quartz assemblage' in $\mathrm{H}$ Moore \& $\mathrm{G}$ Wilson 'Cruester, Bressay, Shetland', Proc Soc Antiq Scot.

Barber, J 1990 'Scottish burnt mounds: variations on a theme', in V Buckley (ed), 98-101.

Barber, J \& Russell-White C J 1990 'Preface', in V Buckley (ed), 59.

Barber, J \& Lehane, D 1990 'Arran: Machrie Moor and Glaister', in V Buckley (ed), 77-9.

Barfield, L \& Hodder, M 1987 'Burnt mounds as saunas and the prehistory of bathing', Antiquity, 61, 370-9.

Beall, F C 1972 'Introduction to thermal analysis in the combustion of wood', Wood Sciences, 5, 102-8.

Birch, S et al forthcoming Uamh an Ard Achadh (High Pasture Cave) \& Environs Project, Strath, Isle of Skye 2007: The preliminary assessment and analysis of Late Prehistoric cultural deposits from a limestone cave and associated surface features. Data Structure Report, HPC 003.

Buckley, V (ed) 1990 Burnt Offerings. International Contributions to Burnt Mound Archaeology. Academic Publications, Wordwell Ltd, Dublin.

Carter, S; Dalland, M \& Long, D 2005 Early Landuse and Landscape Development in Arisaig. SAIR 15, Edinburgh (http://www.sair.org.uk).

Cressey, M \& Strachan, R 2003 'The excavation of two burnt mounds and a wooden trough near Beechwood Farm, Inshes, Inverness, 1999', Proc Soc Antiq Scot, 133 (2003), 191-203.

Cressey, M \& Verrill, L 2006 Palynological Investigations at Carnach Bog, near Arisaig, Highland. CFA Report No 1268, unpublished.

Dearing, J A 1994 Environmental Magnetic Susceptibility: using the Bartington MS2 system. Chi Publishing, Kenilworth.

Dearing, J A 1999 'Magnetic susceptibility', in J Walden; F Oldfield \& J P Smith (eds) Environmental Magnetism: A Practical Guide.
Quaternary Res Assoc Technical Guide, vol. 6, London.

Heawood, R \& Huckerby, E 2002 'Excavation of a burnt mound at Sparrowmire Farm, Kendal', Trans Cumberland Westmorland Antiq \& Archaeol Soc, II (2002), 29-49.

Hedges, J 1975 'Excavation of two Orcadian burnt mounds at Liddle and Beaquoy', Proc Soc Antiq Scot, 106 (1974-5), 39-98.

Kenward, H K; Hall, A R \& Jones, A K G 1980 'A tested set of techniques for the extraction of plant and animal macrofossils from waterlogged archaeological deposits', Science and Archaeology, 22, 3-15.

Lacaille, A D 1951 'A stone industry from Morar, Inverness-shire; its Obanian (Mesolithic) and later affinities', Archaeologia, 94, 103-39.

Neighbour, T \& Johnson, M 2005 'A Bronze Age burnt mound in lowland Cumbria: excavations at Garlands Hospital, Carlisle, 1997', Trans Cumberland Westmorland Antiq \& Archaeol Soc, V (2005), 11-23.

Nixon, M J 1990 'Some south Cumbrian burnt mounds - an initial survey', in V Buckley (ed), 112-4.

O'Kelly, M J 1954, 'Excavation and experiments in ancient Irish cooking sites', Journal of the Royal Society of Antiquaries of Ireland, 84, 105-55.

Peterkin 2007 'Bronze Age brew proves a vintage ale', Sunday Telegraph, 13/08/2007.

Peters, C; Church, M J \& Batt, C M 2004 'Application of mineral magnetism in Atlantic Scotland archaeology 1: techniques, magnetic enhancement and the identification of fuel sources', in $\mathrm{R}$ A Housley \& G Coles (eds) Atlantic Connections and Adaptations: Economies, Environments and Subsistence in Lands Bordering the North Atlantic, 86-98. Symposia Assoc Environ Archaeol, vol. 21, Oxford.

Rees, A R 1996 'Polnish Chapel to Loch Nan Uamh Viaduct', Discovery \& Excavation in Scotland, 58-9.

Russell-White, C J \& Barber, J 1990 'Bute and Islay', in $\mathrm{V}$ Buckley (ed), 82 .

Schweingruber, F H 1992 Microscopic Wood Anatomy. Swiss Federal Institute of Forest, Snow and Landscape Research.

Smart, T L \& Hoffman, E S 1988 'Environmental interpretation of archaeological charcoal', in C A Hastorf \& V S Popper Current Palaeoethnobotany, 65-205. University of Chicago Press, Chicago.

Suddaby, I 2005 (a) 'A830 Upgrading, Loch Nan Uamh to Arisaig, Lochaber, Highland. Updated 
Desk-Based Assessment and Walk-Over Survey'. CFA Report No. 1072, unpublished.

Suddaby, I 2005 (b) 'A830 Upgrading, Loch Nan Uamh to Arisaig, Lochaber, Highland. Mitigation Strategy'. CFA Report No. 1088, unpublished.

Suddaby, I 2007 'Borrodale, Lochaber, Highland, Excavations within the A830 upgrading corridor in 2005, Archive Report'. CFA Archaeology Ltd.

Suddaby, I \& White, R H M 2006 'A830 Upgrading, Loch Nan Uamh to Arisaig, Lochaber, Highland. Archaeological Excavations'. CFA Report No. 1100, unpublished.

Taylor, M 1981 Wood in Archaeology. Shire Publications, Aylesbury. 